\title{
Numerical Analyses of Charpy Impact Test for Welded Joints
}

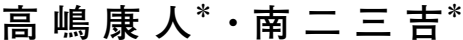 \\ Yasuhito TAKASHIMA and Fumiyoshi MINAMI
}

Key Words: Dynamic Analysis, Dissimilar Joints, Charpy Impact Test, Hertzian Contact Theory

\section{1. 緒言}

構造部材の耐熱性・耐食性向上や輸送機器の軽量化など を目的として適材適所で合理的に異材を組み合わせたいと いうニーズが高まっており、異材接合や特性の異なる異種 鋼板接合に注目が集まっている。異材継手では融合部で強 度や延性・剛性が著しく変化しており、継手の性能を把握 するために強度急変部を対象とした評価方法が望まれる。 また接合部は熱影響による勒性劣化が懸念されるため、十 分な継手破壊性能を確保するにはその勒性を把握すること が重要である。強度急変部を対象にした勒性試験では、例 えば瀬尾らの検討 ${ }^{1)}$ のように切欠き付近に硬化部が隣接す る場合は Fig.1に模式的に示したようにシャルピー吸収エ ネルギーが低下してエネルギー遷移温度が上昇する。この ような強度急変部による影響は定性的には塑性変形を拘束 することで応力が高くなるためと理解されている。この影 響を定量的に把握するためには、実験のみならず様々な支 配因子の影響を独立して考慮できる数值解析的なアプロー チを用いることが望まれる。

ここでとりあげたシャルピー衝撃試験は材料の切欠き勒 性を評価するための試験法として工業的に広く普及して いるが、衝撃負荷を受けるシャルピー試験片の破壊現象を 理解するためには、破壊が生じる切欠き付近の応力場・ひ ずみ場に対する衝撃負荷による動的効果を把握する必要が ある。試験片に作用する衝撃荷重は、実験では計装化した

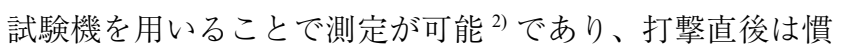
性効果によって大きく変動する。この荷重変動は試験片の 曲げ応力に影響することが予想されるが、応力集中を生じ る切欠き底付近の応力・ひずみがどのように変動するかは 十分に明らかになっていない。また、鋼のような弾塑性材 料を扱う場合には、切欠き付近で塑性変形を生じ、切欠き 底付近の応力・ひずみは周囲の弾性状態の領域による塑性 拘束の影響を受けるため、その挙動がさらに複雑になる と予想される。脆性破壊や延性破壊のローカルアプロー
チ ${ }^{3), 4)}$ により切欠き材の破壊条件に対する理解が深まって いるが、破壊プロセスゾーンの応力履歴、ひずみ履歴は破 壊クライテリオンを考えるうえで極めて重要であり、シャ ルピー試験片の衝撃荷重による慣性効果の把握が課題であ る。

慣性効果は運動方程式を基礎方程式として扱う動的解析 で求められるが、陽解法では収束計算は不要であるものの 安定な解を得るための計算時間増分の制約により、対象と する現象の時間が長い場合は計算コストが高い。材料の延 性脆性遷移温度よりも低温域でのシャルピー衝撃試験のよ うに、巨視的に塑性変形があまり生じない脆性破壊を対象 とする場合は、破壊に至るまでの時間が比較的短いため（例 えば吸収エネルギーが $50 \mathrm{~J}$ のとき $0.5 \times 10^{-3}$ 秒程度)、近年 の計算機性能の向上もあって動的陽解法を用いた 3 次元モ デルの数值解析が十分に実施可能であると考えられる。先 行研究 ${ }^{5)-11)}$ におけるシャルピー試験片の動的解析は 2 次元 モデルが多く用いられているが、ひずみエネルギーは 2 次 元平面ひずみモデルを厚さ相当分換算した值と 3 次元モデ ルで求めた值で異なることが指摘されており、打撃直後の 試験片の運動エネルギーや変形エネルギーの変化を 3 次元

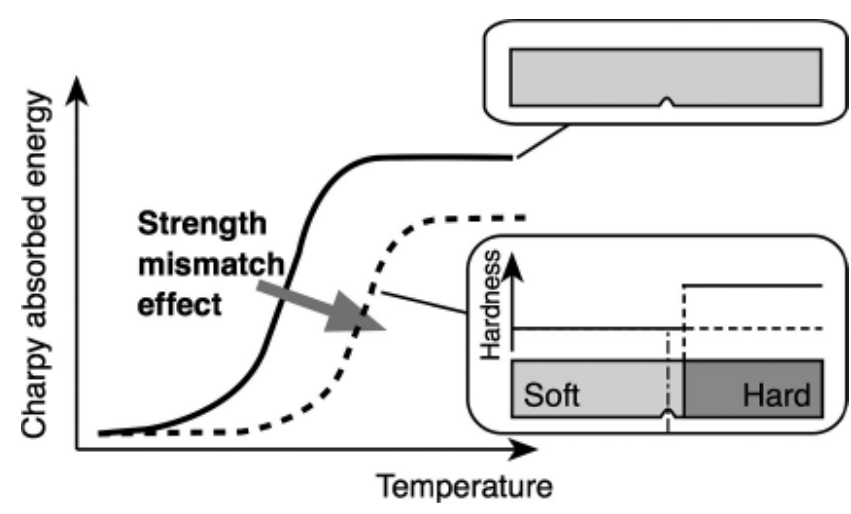

Fig.1 Schematic illustration of strength mismatch effect on Charpy absorbed energy.

*大阪大学 接合科学研究所（７ 567-0047 大阪府茨木市美穂ヶ 丘 11-1）

Joining and welding research Institute, Osaka University (11-1 Mihogaoka, Ibaraki, Osaka,567-0047 Japan) 
モデルで詳細に把握することが必要である。

著者らは 3 次元モデルを用いたシャルピー衝撃試験の数 值解析に取り組んでおり、動的負荷によるひずみ速度や温 度上昇を考慮した解析を駆使して、鋼シャルピー試験片や その溶接・接合部の試験片の脆性破壊現象を扱い、その破 壊機構の理解を深めてきた ${ }^{12)-18)}$ 。特に、溶接・接合部の強 度不連続によって塑性変形を拘束するような場合は 3 次元 で変形や応力を考慮することが大切で、古くから実験的に 検討されてきたシャルピー吸収エネルギーに対する強度不 連続部の影響を説明するために重要である。本稿では、著 者らがこれまでに取り組んだシャルピー試験片の動的シ ミュレーション ${ }^{16)}$ の内容を中心に、接合部シャルピー試験 片の解析結果 ${ }^{14)}$ を紹介する。

\section{2. シャルピー試験片の衝撃応答特性とその動的シミュ レーション}

シャルピー試験片に作用する荷重は、慣性の影響で打撃 直後は著しく振動する。計装化シャルピー衝撃試験で計測 された荷重－荷重点変位関係の一例を Fig.2 に示す。同じ 条件で 2 回実施したときの試験片 $\mathrm{A}$ と試験片 B の結果を示 しているが、荷重応答はどちらの試験片でも同じように振 動しており、ほぼ再現されている。これは、この振動が試 験片のもつばらつきではなく、慣性によってもたらされた ものであることを意味する。試験片 A と試験片 B の結果を 比較すると、試験片 $\mathrm{A}$ に脆性破壊が生じて荷重が急激に低 下する段階よりも小さな変形の時点で試験片 $\mathrm{B}$ の脆性破壞 が生じていることがわかる。この試験片 B の脆性破壊発生 時における荷重は、それまでに試験片に作用した最大荷重 よりも低いことがわかる。このような破壊現象を取り扱う 場合には、衝撃試験中の慣性の影響を考慮しておくことが 大切であり、それを理解するための数值解析が有用となる。

シャルピー試験片に対する衝撃負荷による動的効果を考 慮した数值解析が 1970 年代後半から多くの研究者によっ て取り組まれてきた。Ayres ${ }^{5)}$ は、汎用コードMARCを用い て予き裂入りシャルピー試験片の 2 次元平面ひずみ動的弾 塑性 FEM 解析を実施し、圧力容器用鋼の予き裂入り試験 片を計装化試験（打撃速度 $1.8 \mathrm{~m} / \mathrm{s}$ ) で測定した荷重履歴と 比較している。Ayres ${ }^{5)}$ の数值解析では変動する荷重がピー クとなるタイミングは一致しなかったが、その周期は $40 \mu \mathrm{s}$ で実験と対応したと述べている。荷重がピークとなる時刻 の不一致は、試験片に作用する打撃点での荷重と実験で打 撃ハンマーに貼り付けたひずみゲージで計測する位置の違 いに起因するのではないかとしている。

また、Norris ${ }^{(6)}$ は、A533 鋼のV 字切欠きシャルピー試 験片を対象とした 2 次元平面ひずみ動的弾塑性 FEM 解

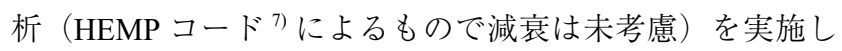
た。試験片への衝撃荷重の載荷方法について、打撃部の接 触形状が曲面であるか平面であるかの違いによる応力場へ

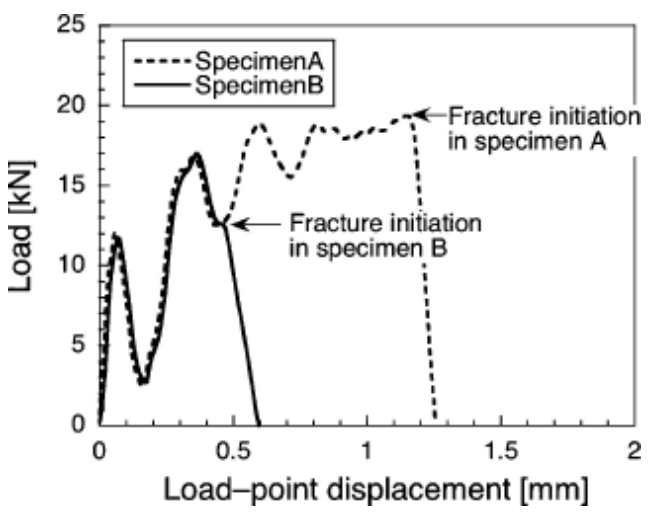

Fig.2 Load record measured by instrumented Charpy impact testing machine.

の影響を検討しているが、試験片の塑性変形挙動には差が 生じたが切欠き底付近の応力にはあまり影響しなかった。 Ayres $^{5)}$ と同様に、試験片の打撃点での荷重は打撃ハンマー に貼り付けたひずみゲージから求めた值と同期していない と述べている。数值解析で実験を再現するためには、打撃 部の接触問題の取り扱いが重要であることが示唆されてい る。

Tvergaard ${ }^{8)}$ は、V 字切欠きシャルピー試験片の 2 次元 平面ひずみモデルを用いて動的陽解法による弾塑性 FEM 解析を実施し、Gurson モデルによる延性破壊条件と最大主 応力による脆性破壊条件を用いた破壊判定により延性脆性 遷移挙動について検討した。吸収エネルギーの温度依存性 は、強度のひずみ速度依存性と温度依存性を数值解析に反 映させることで求められるとしているが、実験との対応性 は全く示されていない。Mathur ら ${ }^{9)}$ は、Tvergaard ${ }^{8)}$ の 2 次元モデルでの解析を 3 次元に拡張し、動的陽解法によ る 3 次元弾塑性 FEM 解析を実施した。強度のひずみ速度 依存性や温度依存性を組み入れて計算しているが、高速変 形に伴う温度上昇は計算されていない。応力分布は 3 次元 モデルの表面付近では 2 次元モデルと大きく異なるが、試 験片厚さ中央断面では平面ひずみ条件での 2 次元解析結果 とよく対応したと報告している。一方で、試験片のひずみ エネルギーは 2 次元モデルに比べて 3 次元モデルの方が 10 $\%$ 程度小さかった。この解析でも実験との対応性は全く議 論されていないが、シャルピー試験片の 3 次元モデルと 2 次元モデルの解析結果の違いについての知見が得られてい る。

Rossol ${ }^{10)}$ は、標準 V 字切欠きシャルピー試験片への 動的効果と塑性拘束状況を理解する目的で、汎用コード ABAQUS 5.4 を用いてシャルピー試験片の 2 次元動的弾塑 性 FEM 解析および 3 次元準静的弾塑性 FEM 解析を実施し、 実験結果と比較して検討した。解析では断熱モデルで発熱 による温度上昇を求め応力解析と連成させており、切欠き 底では温度上昇によって応力が低下することを指摘してい 
る。打撃ハンマーと試験片の接触を考慮して解析している が、摩擦係数は試験片に作用する荷重に対してほとんど影 響しないと報告している。実験で計測した荷重の周期が数 值解析結果と一致しない原因は試験機の剛性によるものと 考察しており、低ブロー試験によって試験機コンプライア ンスを求めて数值解析に反映させることを提案している。 ただし、3 次元モデルの動的解析は実施していない。

Lenkey ら ${ }^{11)}$ は、フェライト鋼のV 字切欠きシャルピー 試験片と予き裂入りシャルピー試験片について、汎用コー ドMARCを用いて 2 次元および 3 次元モデルの準静的陰解 法弾塑性 FEM 解析と Newmark の直接積分法を用いた動的 陰解法弾塑性 FEM 解析を実施した。動的解析で求めた荷 重一変位関係は、計装化試験で測定された荷重信号と変位 の関係とよく対応したと報告している。打撃ハンマーを部 分的に 3 次元要素でモデル化しており、その密度は鋼の場 合に比べて 3 オーダー大きい值を設定しているが、設定の 根拠は示されておらず、正確なモデル化のためには議論の 余地があると思われる。

著者らは、これまでの研究により、試験片と打撃ストラ イカーの接触剛性が打撃直後の荷重振動に影響することを 明らかにし、Hertzの接触理論をふまえたモデル化によって 計装化シャルピー試験の荷重応答特性を数值解析で再現で きることを確認した ${ }^{16)}$ 。シャルピー試験片と打撃ストライ カーの間の接触剛性は、打撃による押込量 $\delta[\mathrm{mm}]$ と打撃部 に作用する単位長さあたりの荷重 $\bar{P}[\mathrm{~N} / \mathrm{mm}]$ の関係として Hertzの接触理論によって定義でき、互いに交差する円筒の 接触に対する次式 ${ }^{19)}$ を用いて与えた。

$$
\delta=\frac{2\left(1-v^{2}\right)}{\pi E} \bar{P} \ln \left(\frac{\pi E\left(R_{1}+R_{2}\right)}{2 \bar{P}\left(1-v^{2}\right) R_{1} R_{2}}\right)
$$

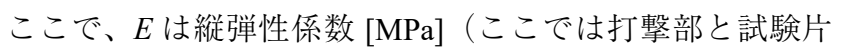
で同じ材質と前提）、vはポアソン比、 $R_{1}$ はストライカーの 刃先半径 $[\mathrm{mm}]$ であり、 $R_{2}$ は試験片表面の曲率で平坦すな わち無限大とした。このようなモデル化によって得られた

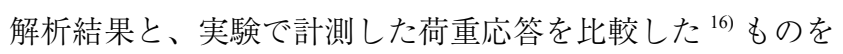
Fig.3に示す。また、従来の解析のように剛接触でモデル 化した結果を合わせて示している。剛接触でモデル化した 場合には荷重が振動するものの振動周期やその大きさが実 験結果とあまり一致していない。一方で、Hertzの接触理論 をふまえたモデル化により、衝撃荷重の大きさや振動周期 が忠実に再現できていることがわかる。

\section{3. 接合部シャルピー試験片の動的 3 次元有限要素モデル}

汎用コード Abaqus/Explicit ver. 6.12 を用いてシャルピー 試験片とストライカーの接触剛性を考慮した動的陽解法弾 塑性有限要素解析を実施した。解析の対象は Fig.4に示す ような強度の異なる鋼を接合した強度急変部のあるシャル ピー試験片 ${ }^{14)}$ で、切欠きは強度の低い側に存在する。こ

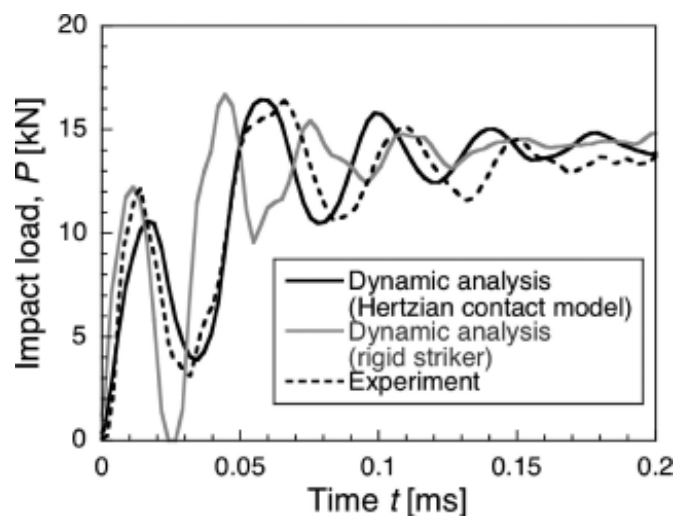

Fig.3 Comparison of measured load - time curve with that computed by dynamic analysis with Hertzian model and rigid connection model.

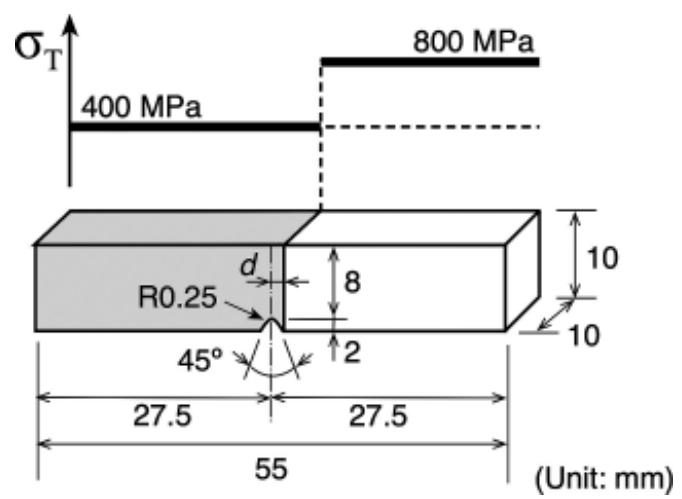

Fig.4 Charpy specimen of dissimilar steel joints.

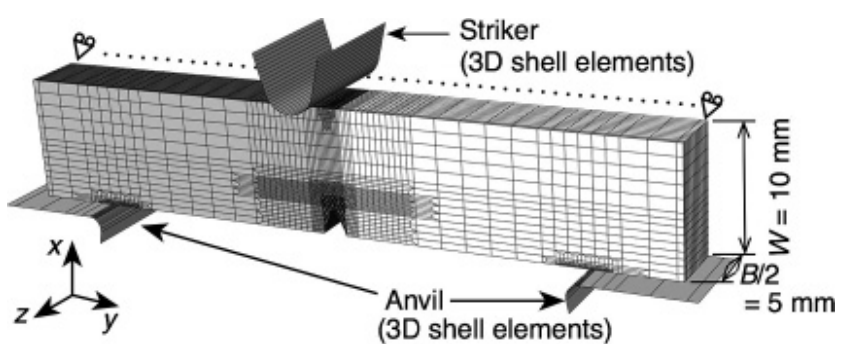

Fig.5 Mesh division of the Charpy specimen for dissimilar joints.

の解析に用いた要素分割について Fig.5に示す。試験片の 対称性を考慮して厚さ方向で $1 / 2$ 部分をモデル化した。試 験片は 3 次元 6 面体ソリッド要素で分割し、打撃ストライ カーとアンビルは 3 次元剛体シェル要素でモデル化してい る。打撃はストライカーに強制変位を与えて試験片に衝突 させることでモデル化し、その変位速度は一般的なシャル ピー試験機で振子式ハンマーのエネルギー保存則から求め られる $5 \mathrm{~m} / \mathrm{s}$ とした。この解析手法の概要を Fig.6にまとめ た。ストライカーと試験片の接触問題には式（1）で示した Hertzの接触理論に基づいて解析した。ひずみ速度と温度上 昇が流動応力に及ぼす影響は次のように考慮した。シャル 


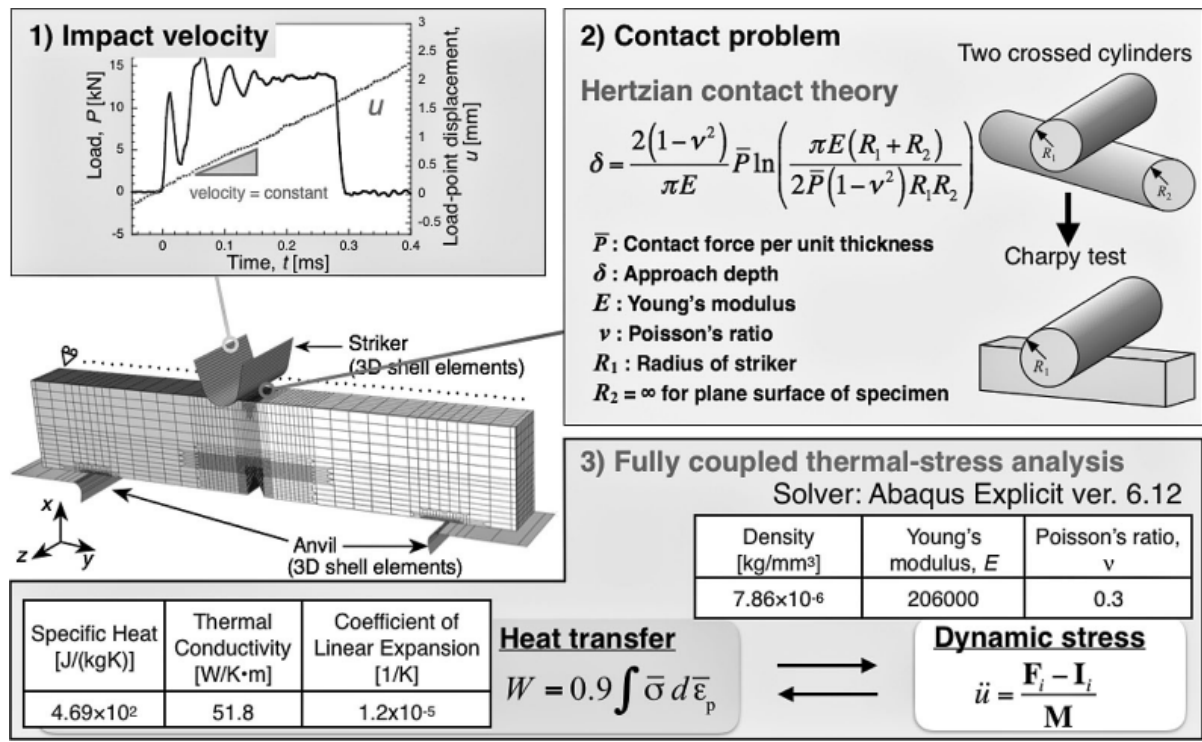

Fig.6 Summary of numerical model for dynamic analysis used in this study.

Table 1 Thermal constants used for FE analysis.

\begin{tabular}{|c|c|c|c|}
\hline$C[\mathrm{~J} / \mathrm{kg} \cdot \mathrm{K}]$ & $\rho\left[\mathrm{kg} / \mathrm{mm}^{3}\right]$ & $\lambda[\mathrm{W} / \mathrm{K} \cdot \mathrm{mm}]$ & $\alpha_{\mathrm{L}}[1 / \mathrm{K}]$ \\
\hline $4.69 \times 10^{2}$ & $7.86 \times 10^{-6}$ & $5.18 \times 10^{-2}$ & $1.2 \times 10^{-5}$ \\
\hline
\end{tabular}

$C$ : Specific heat, $\rho$ : Density, $\lambda$ : Thermal conductivity, $\alpha_{\mathrm{L}}$ : Coefficient of linear expansion

Table 2 Mechanical properties used for FE analysis.

\begin{tabular}{|c|c|c|c|c|c|}
\hline & $E[\mathrm{MPa}]$ & $v$ & $\sigma_{\mathrm{Y}}[\mathrm{MPa}]$ & $\sigma_{\mathrm{T}}[\mathrm{MPa}]$ & $\varepsilon_{\mathrm{T}}[\%]$ \\
\cline { 1 - 4 } TS400 & \multirow{2}{*}{206000} & \multirow{2}{*}{0.3} & 300 & 400 & 26 \\
\cline { 1 - 2 } TS800 & & & 720 & 800 & 10 \\
\hline
\end{tabular}

$E$ : Young's modulus, $v$ : Poisson's ratio, $\sigma_{\mathrm{Y}}$ : Yield stress, $\sigma_{\mathrm{T}}$ : Tensile strength, $\varepsilon_{\mathrm{T}}$ : Uniform elongation

ピー試験片の温度上昇は Table 1 に示す鋼の熱伝導物性值 を用いて熱伝導解析によって計算し、断熱塑性変形による 発熱は Taylor と Quinney の報告 ${ }^{20)}$ を参考に塑性仕事の 9 割 が熱エネルギーに換算されるとした。この計算で求めた温 度上昇は応力解析に反映し、熱伝導解析と応力解析を完全 に連成した解析を行った。

解析に用いる材料特性は、これまでの検討 ${ }^{14)}$ で用いた軟 鋼と高強度鋼を想定した特性である Table 2 に示すような 值を採用した。これは室温・静的条件下でのヤング率とポ アソン比、降伏応力、引張強さ、一様伸びである。本研究 の対象のように室温付近ではヤング率やポアソン比の温度 依存性やひずみ速度依存性は小さいとみなし一定とした。 降伏応力と引張強さの温度依存性やひずみ速度依存性は、 Bennett と Sinclairにより提案されたひずみ速度－温度パラ メータ $R^{21)}$ を用いて温度と等価な影響をもつと考えて設定 した。降伏応力は室温の值から日本溶接協会 $\mathrm{BE}$ 委員会で 提案された関係式を用いて計算し、引張強さも同様の温度
依存性をもつと仮定して計算した。一様伸びは温度やひず み速度の影響を受けないものとし、任意の温度とひずみ速 度における応力ーひずみ関係は次式の Swift 則に従うとし て設定した。

$$
\bar{\sigma}=\sigma_{\mathrm{Y}}\left\{1+\left(\bar{\varepsilon}_{\mathrm{p}} / \alpha\right)^{\mathrm{n}}\right\}
$$

ここで、デは相当応力 $[\mathrm{MPa}] 、 \bar{\varepsilon}_{\mathrm{P}}$ は相当塑性ひずみ、 $n$ は 加工硬化指数、 $\alpha$ は材料定数である。 $n$ と $\alpha$ の值は降伏応 力と引張強さ、一様伸びに応じて一義的に定まるため、任 意の温度とひずみ速度における值を求めて採用した。

\section{4. 動的シミュレーションによる接合部シャルピー試験片 の応力ひずみ場の可視化}

強度急変部のあるシャルピー試験片の動的シミュレー ションによって得られた塑性ひずみエネルギー密度分布を Fig.7に示す。試験片全体に蓄えられた吸収エネルギーが $20 \mathrm{~J}$ となる時点の結果を示している。また、強度急変部の 影響を把握するため比較として強度急変部の存在しない材 料 TS400のみで構成された均質試験片の結果も示している。 均質試験片では V 字切欠きを中心として左右対称に塑性変 形が生じるため、塑性ひずみエネルギー密度分布も切欠き を中心にして対象な広がりを示している。これに対して切 欠き付近に硬い材料 TS800 が存在する接合部試験片では、 TS800 部分ではほとんど塑性変形が生じないために塑性ひ ずみエネルギーを吸収しておらず、変形が非対称となって 塑性ひずみエネルギー密度分布も非対称に広がっている。 シャルピー吸収エネルギーは試験片に蓄えられたひずみエ ネルギーの総和であるが、強度急変部のある試験片では塑 性ひずみエネルギーの蓄えられる領域が大きく異なってお り、シャルピー吸収エネルギーのもつ意味も均質試験片の 
場合と異なることがわかる。これは、実験でシャルピー吸 収エネルギーに強度急変部の存在が影響したことと関連し て、その結果の解釈に注意が必要であることを示唆してい る。

このように、動的シミュレーションによって接合部シャ ルピー試験片の応力ひずみ場を可視化することができ、強 度急変部の存在がもたらす影響を把握することができる。 シャルピー試験片では、衝撃負荷の作用によりひずみ速度

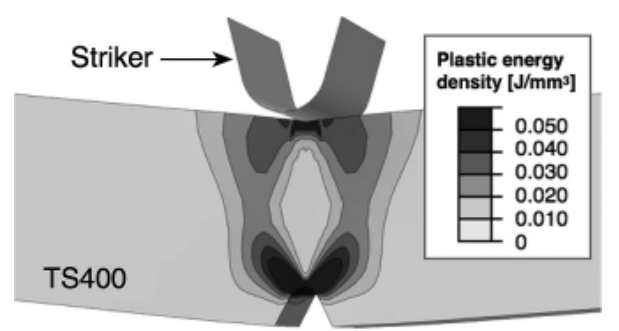

(a) Homogeneous specimen

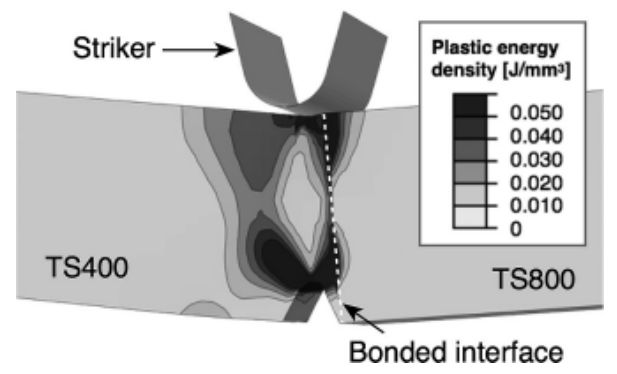

(b) Joint specimen

Fig.7 Distribution of plastic strain energy density in Charpy specimen $\left({ }_{\mathrm{v}} E=20 \mathrm{~J}\right)$.
が大きくなることや、切欠き付近の温度上昇は試験片の破 壊挙動に影響することが考えられる。延性脆性遷移挙動を 示す鉄鋼材料では、一般にひずみ速度が大きくなると脆性 破壊しやすくなり、温度が高くなると脆性破壊しにくくな る。シャルピー衝撃試験では同じ打撃速度を用いているが、 試験片に生じるひずみ速度や温度上昇は強度急変部の存在 によって異なることが予想される。

この解析で求めた、試験片全体で蓄えられる吸収エネル ギーが $20 \mathrm{~J}$ のときの切欠き付近のひずみ速度分布を Fig.8 に示す。なお、この図は試験片の厚さ中央断面でのひずみ 速度分布を示している。試験片表面では平面応力状態とな るが、内部では厚さ方向の変形が拘束されることによって 平面ひずみ状態に近づき、その結果として高い応力が発生 するため、脆性破壊は試験片表面よりも内部から発生しや すい。このような試験片内部の状態は、たとえ高速カメラ を用いて衝撃試験の様子を撮影したとしても把握すること はできないが、このように 3 次元動的シミュレーションを 行うことで可視化することが可能である。試験片厚さ中央 のひずみ速度分布は、均質試験片と強度急変部を含む接合 部試験片では大きく異なっており、接合部試験片では非対 称な分布となっている。また、硬い材料 TS800 部分ではひ ずみ速度があまり大きくないため、その部分では脆性破壊 が生じにくくなる。

試験片内部での温度上昇は実験で直接計測することが難 しく、このような 3 次元シミュレーションの威力が発揮され る。ここでは、切欠き付近の温度上昇について解析した結果 を Fig.9に示す。試験片全体で蓄えられる吸収エネルギーが $20 \mathrm{~J}$ のときの結果を示しており、切欠き底では $100{ }^{\circ} \mathrm{C}$ 程度の

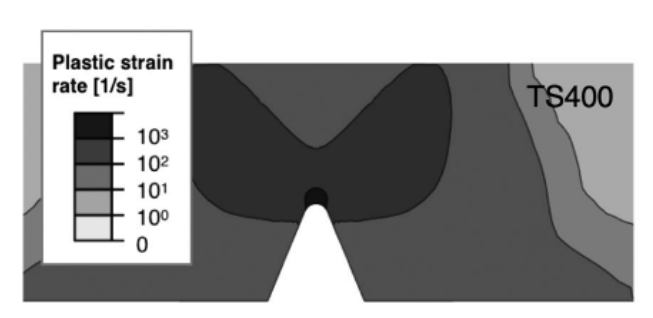

(a) Homogeneous specimen

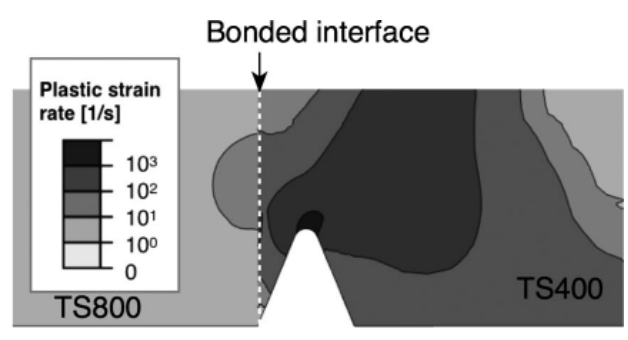

(b) Joint specimen

Fig.8 Distribution of plastic strain rate near the V-notch in Charpy specimen $\left({ }_{\mathrm{v}} E=20 \mathrm{~J}\right)$.

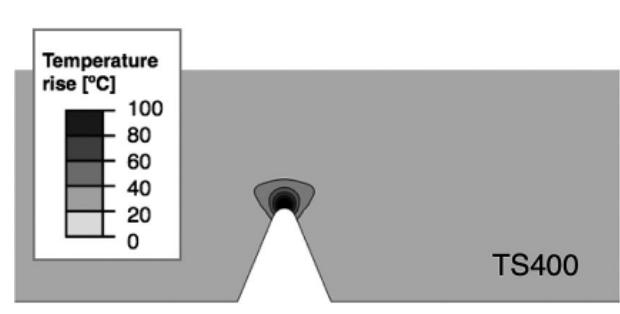

(a) Homogeneous specimen

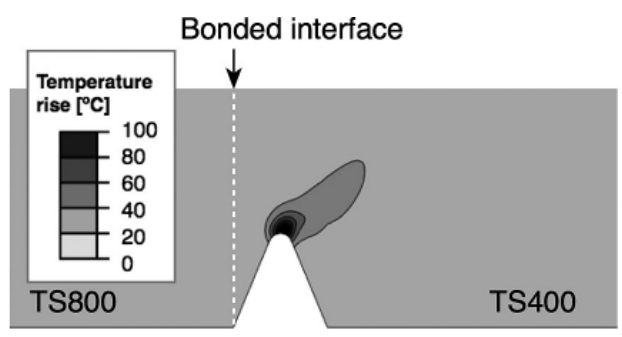

(b) Joint specimen

Fig.9 Distribution of temperature rise during impact loading near the V-notch in Charpy specimen $\left({ }_{\mathrm{v}} E=20 \mathrm{~J}\right)$. 


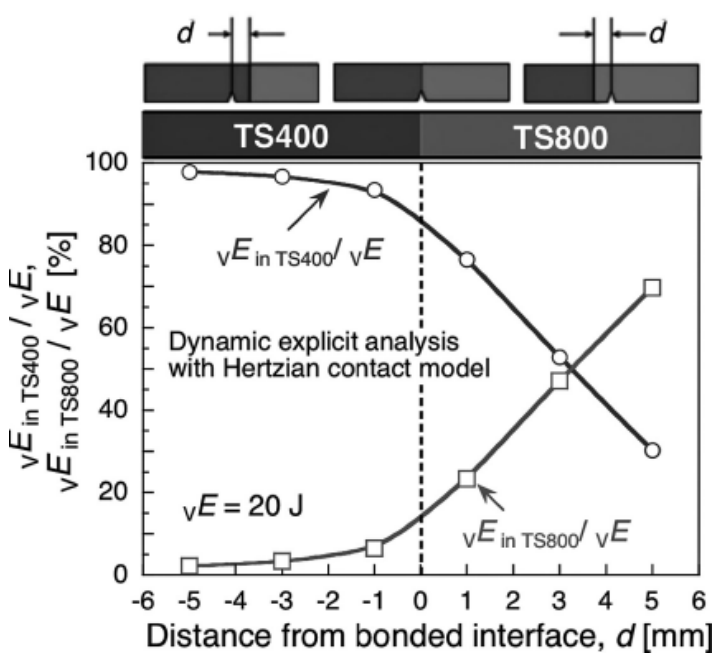

Fig.10 Relationship between V-notch location and absorbed strain energy $\left({ }_{\mathrm{v}} E=20 \mathrm{~J}\right)$.

温度上昇が生じている。また、強度急変部のある接合部試 験片では温度上昇する範囲が均質試験片と異なっており、 隣接する硬い部分で温度上昇が生じない代わりにその反対 側で温度上昇する範囲が広がっていることがわかる。

このように、ここで紹介した 3 次元動的シミュレーショ ン手法を用いることで実験では計測が困難な試験片内部の ひずみ速度や温度上昇などを解析することが可能であり、 強度急変部のある試験片のひずみエネルギー分布も把握す ることができる。異材継手シャルピー試験片において異材 それぞれに蓄えられるひずみエネルギーについて、切欠き の位置と関連させて試験片全体のエネルギーに対する割合 をまとめた結果を Fig.10に示す。なお、この内容は慣性力 の影響を無視した準静的解析によって得られた結果を既に 報告 ${ }^{14)}$ しているが、ここでは、慣性力を考慮した 3 次元動 的解析の結果を示している。切欠きが融合部よりも低強度 側にある場合には、そのほとんど（90\%以上）が低強度側 の材料で吸収していることがわかる。一方で、切欠きが高 強度側にある場合でも、低強度側でひずみエネルギーが吸 収される割合が大きい。高強度側で蓄えられるひずみエネ ルギーは融合部から切欠き底までの距離 $d$ に強く依存して おり、この解析のように強度の差が 2 倍の接合部の場合で は $d$ が $3 \mathrm{~mm}$ 以下の場合は低強度側で蓄えられるエネルギー の方が大きい。この結果は、高強度側に切欠きを入れたシャ ルピー試験片で勒性を評価するうえで、切欠き位置の影響 が大きいことを示している。

\section{5. 結 言}

これまでに著者らが取り組んだシャルピー試験片の動的 シミュレーションの内容を中心に、接合部シャルピー試験 片の解析結果について示した。要約を以下にまとめる。

1）異材接合部のように強度急変部のあるシャルピー試験片
では、試験片が非対称に変形することによって蓄えられ るひずみエネルギーの分布も非対称になる。そのため、 試験片全体に吸収されるエネルギーが同じであっても塑 性ひずみエネルギーの蓄えられる領域が大きく異なる。 強度急変部を対象としたシャルピー衝撃試験では、その 結果の解釈に注意が必要であることを示唆している。

2）著者らが実施した 3 次元動的シミュレーションにより、 実験では計測が困難な試験片内部のひずみ速度や温度上 昇などを解析することが可能である。例えば、試験片全 体で蓄えられる吸収エネルギーが $20 \mathrm{~J}$ のと、切欠き 底では $100{ }^{\circ} \mathrm{C}$ 程度の温度上昇が生じている。温度上昇す る範囲は低強度側に広がることなどが定量的に把握でき る。

3）シャルピー試験片と打撃ストライカーのあいだの接触問 題を Hertz 理論に基づいて解析することにより、試験片 に作用する荷重の振動に対する慣性の影響を忠実に再現 できる。今後、このシミュレーション手法を駆使するこ とで、接合部の衝撃特性に対する理解を一層深められる ことが期待される。

\section{引用文献}

1）瀬尾健二、野方文雄、正木順一：材質的不連続部を含む材の シャルピー吸収エネルギに関する研究、材料、35 (1986) 14051410.

2) F. Fearnehough, C. Hoy: Mechanism of deformation and fracture in the Charpy test as revealed by dynamic recording of impact loads, Journal of the Iron and Steel Institute, 202 (1964) 912-920.

3) A. Pineau: Development of the local approach to fracture over the past 25 years: theory and applications, International Journal of Fracture, 138 (2006) 139-166.

4) F.M. Beremin: A local criterion for cleavage fracture of a nuclear pressure vessel steel, Metallurgical and Materials Transactions A, 14 (1983) 2277-2287.

5) D.J. Ayres: Dynamic plastic analysis of ductile fracture - the Charpy specimen, Int. J. Fract., 12 (1976) 567-578.

6) D.M. Norris Jr.: Computer Simulation of the Charpy V-Notch Toughness Test, Eng. Fract. Mech., 11 (1979) 261-274.

7) M.L. Wilkins: Calculation of elastic-plastic flow. Lawrence Livermore Laboratory Rep., UCRL-7322 Rev. 1. (1969).

8) V. Tvergaard, A. Needleman: An analysis of the temperature and rate dependence of Charpy V-notch energies for a high nitrogen steel, Int. J. Fract., 37 (1988) 197-215.

9) K.K. Mathur, A. Needleman, V. Tvergaard, V. Tvergaard: Dynamic 3D analysis of the Charpy V-notch test, Modelling and Simulation in Materials Science and Engineering, 1 (1993) 467-484.

10) A. Rossoll, C. Berdin, P. Forget, C. Prioul, C. Prioul, B. Marini, et al.: Mechanical aspects of the Charpy impact test, Nuclear Engineering and Design, 188 (1999) 217-229.

11) G.B. Lenkey, Z. Balogh, N. Hegman: Finite Element Modelling of Charpy Impact Testing, Transferability of Fracture Mechanical Characteristics, Nato Science Series II, 78 (2002) 291-302. 
12) Y. Takashima, M. Ohata, F. Minami: Analysis of Statistical Scatter in Charpy Impact Toughness, Mater. Sci. Forum, 783-786 (2014) 23942399.

13) Y. Takashima, T. Nishi, H. Shoji, H. Shoji, M. Ohata, F. Minami: Evaluation method for Charpy impact toughness of laser welds based on lateral contraction analysis, Weld World, 58 (2014) 289-295.

14) Y. Takashima, Y.S. Yamada, T. Handa, S. Igi, K. Oi, F. Minami: Numerical analysis of strength mismatch effect on stress field in Charpy specimen, Weld World, 59 (2015) 433-441.

15) Y. Takashima, M. Ohata, K. Inose, H. Yamaoka, Y. Nakanishi, F. Minami: Evaluation of Charpy impact toughness using side-grooved specimen for hybrid laser-arc welds of ultra-high-strength steel, Weld World, 60 (2016) 1191-1199.

16) Y. Takashima, T. Handa, F. Minami: Three-Dimensional Dynamic Explicit Finite Element Analysis of Charpy Impact Test, Mater. Sci. Forum, 879 (2017) 1905-1910.

17) Y. Takashima, T. Kawabata, S. Yamada, F. Minami: Observation of micro-cracks beneath fracture surface during dynamic crack propagation, Theoretical and Applied Fracture Mechanics, (2017) In press.

18) Y. Takashima, F. Minami: Influence of impact velocity on transition time for V-notched Charpy specimen, 溶接学会論文集, 35 (2017) 80-84.

19) W. Goldsmith, "Impact” , Edward Arnold Ltd., London, (1960).

20) G.I. Taylor, H. Quinney: The latent energy remaining in a metal after cold working, Proceedings of the Royal Society of London Series a-Containing Papers of a Mathematical and Physical Character, 143 (1934) 307-326.

21) P.E. Bennett, G.M. Sinclair: Parameter Representation of LowTemperature Yield Behavior of Body-Centered Cubic Transition Metals, Transactions of the American Society of Mechanical Engineers, 88 (1966) 518-524.

\section{代表者メールアドレス}

高嶋康人 takashima@jwri.osaka-u.ac.jp 